\title{
Strategic Resilience: A Case of Collaborative Exploration of Land-use Planning and Total Defence
}

\author{
Christofer Tolis \\ Combitech $\mathrm{AB}$ \\ Gustavslundsvägen 42, 3 tr \\ SE-167 51 Bromma \\ Sweden \\ Email: christofer.tolis@combitech.se
}

\section{Abstract}

Strategic resilience concerns broad societal issues and long-term processes to successfully handle severe disturbances such as crises and war. This paper presents a case study of a Swedish exploration project to investigate how civil defence interests may influence land-use planning through legislation on national interests. The project brought together two disparate areas and involved collaborative exploration through representatives from both communities. Through a large workshop, representatives from a number of governmental agencies came together to develop and discuss examples of national interests for civil defence. Continued work following the workshop revealed five key questions, each contributing towards a shared understanding of specific possibilities and limitations. The questions concerned issues of boundaries, contents, importance, location, and value, thereby providing input to a proposed sector description to be used when deciding whether to start handling actual national interest claims for civil defence or not. Through the work reported, the paper illustrates recurring challenges with handling divergent and shared meanings, balancing of logical and physical aspects, and bridging of means and ends in collaborative exploration.

Keywords Collaborative exploration, Civil defence, National interests. 


\section{Introduction}

How our society use its resources and how we defend it are two areas of concern for many people. Not only professionals in each area, but also ordinary people care about their living environment and their safety. Despite different challenges and possibilities within the two areas, they can be seen to meet in the concept of resilience, especially from a large-scale and long-term strategic perspective. Resilience is commonly used to describe a wide range of complex systems (cf. Nelson et.al. 2007) and has been applied to for example individuals, organisations, and nations. Distinguishing between "stability" and "resilience", Holling (1973) describes the latter property as "a measure of the persistence of systems and of their ability to absorb change and disturbances and still maintain the same relationships between populations or state variables" (ibid., p. 14).

But how can the relationship between land-use planning and total defence work in practice, influencing strategic resilience? And how can this relationship be explored to collectively identify challenges and develop possibilities? Although allowances in Swedish law for letting both military and civil defence interests influence land-use planning have existed for some thirty years, these provisions have so far only been utilised by the military side. A legal framework of so-called national interests provides the possibility of taking into account also the civil side of total defence, along with a number of other sectors such as communications, cultural heritage, and industrial development (SFS 1998:808).

\subsection{Focus of paper}

In early 2017, the Swedish Civil Contingencies Agency procured an exploration project to be performed by a large consulting company. The company agreed to the task of developing a proposal for a so called sector description for the agency to use in deciding whether or not to begin utilising the national interest legislation for civil defence.

This paper documents the design, execution, results and experiences of the project in the form of a case study (cf. Yin 2003). It covers the period from April to September 2017, when the work was performed by the author together with a consultant colleague and two representatives for the Swedish Civil Contingencies Agency. The aim of the paper is to provide insights for those involved in land-use planning and total defence, as well as researchers interested in the collaborative exploration. The content of this paper represents the experiences of the author and does not necessarily correspond to the views of the agency.

From a practical perspective, this work highlights issues of collaboratively working to define a joint domain of concern that brings together two disparate areas. It provides experiences and insights into the exploration of needs and solutions. It also enables results of interest for each area individually. From a theoretical perspective, the work identifies main challenges relevant to collaborative exploration efforts. It provides the opportunity to further the understanding of joint development across organisational and community boundaries by gradually utilising ideas from knowledge management, business development, and information systems development.

\subsection{Methodology and structure}

From a methodological point-of-view, the work undertaken has been driven by explicit requirements to practically support the agency in reaching the outcomes desired. Following this, the author has employed a clinical perspective of helping the client (Schein 1987), focusing on the issues at hand rather than applying a prescribed method or framework. The work can thus be seen as mainly empirically driven, based on a specific context and organisational setting. Instead of starting from theoretically derived propositions, the work has been guided by a bottom-up grounded theory-like approach (Glaser and Strauss 1967). Given the explorative character of the project, practical relevance has been stressed over theoretical rigor (cf. Keen 1991).

All this has consequences for the content of the paper. To provide as rich insights as possible, the majority of the references used are the ones that directly appeared in the exploration project. A limited set of additional references have been added after the completion of the project, mostly in order to set the stage in this introduction and to illustrate the theoretical underpinnings influencing the work and the conclusions.

Following this introduction, the remainder of the paper is structured in four main sections: background, workshop results, key questions, and conclusions. 


\section{Background}

Because the project brings together two areas, land-use planning and total defence, this section gives a background to each. Based on the larger context, the specific issues of each area are highlighted to set the stage for the project and its results.

\subsection{Land-use planning and national interests}

Planning the future of a society has many contributing aspects. A key aspect is land-use planning, dealing with how we best make use of available land and water. The physical environment is shaped through various plans and ultimately decisions on different levels. Legislation provides the legal basis for handling different interests in the planning process, prescribing principles, activities and documents.

How a specific piece of land or water is being used over time is influenced by a number of planning decisions. These are governed by a range of laws regarding the development of facilities such as houses, roads, railways, airports, pipelines for natural gas, high-voltage electricity cables, etc. The particular regulations for each type of facility are guided by references to more overarching values and principles contained in the so called Environmental code (SFS 1998:808), Sweden's core legislation in the environmental area.

As one means of balancing individual interests, the Environmental code details the concept of national interests. National interests are specified in two forms, both as particular geographic areas and as particular types of activities that may need protection. In total, there are twelve activity types that are candidates for national interests, and for each of them one or two governmental agencies are nominated for providing relevant information within their areas of responsibility (SFS 1998:896), as shown in table 1 below.

\begin{tabular}{ll}
\hline National interest & Governmental agency \\
\hline Reindeer herding & Sami Parliament \\
Professional fishing & Swedish Agency for Marine and Water Management \\
Natural heritage and outdoor life & Swedish Environmental Protection Agency and \\
& Swedish Agency for Marine and Water Management \\
Cultural heritage & Swedish National Heritage Board \\
Geological prospecting & Geological Survey of Sweden \\
Industrial production & Swedish Agency for Economic and Regional Growth \\
Energy production and distribution & Swedish Energy Agency \\
Nuclear waste deposition & Swedish Radiation Safety Authority \\
Communications & Swedish Transport Administration and \\
Waste management & Swedish Post and Telecom Authority \\
Water supply & Swedish Environmental Protection Agency \\
Total defence & Swedish Agency for Marine and Water Management \\
& Swedish Armed Forces and \\
\hline
\end{tabular}

Table 1. Overview of legislated types of national interests with nominated actors

The governmental agency responsible for overseeing the whole national interest system is the National Board of Housing, Building and Planning, and they interact with each of the national interest agencies for each societal sector (Boverket 2013). Specifically, for the total defence sector, the legislation prescribes that "Land and water areas of relevance for total defence shall as far as possible be protected from actions that significantly may counteract total defence interests. Areas that are of national interest because they are needed for total defence facilities shall be protected from actions that significantly may hinder the creation or use of the facilities" (SFS 1998:808, 3 chapter 9 §). 


\subsection{Total defence and civil defence}

For the last couple of years, the focus of defence issues in Sweden has increased. Beside the military side, this has meant a renewal of interest also for civil defence; the two together comprising what is known as total defence. According to relevant law, "Total defence are activities needed to prepare Sweden for war. To strengthen the defence capability of the country, the alert level can be heightened. Heightened alert is either high alert or highest alert. During highest alert, total defence is all societal activities that are to be performed. Total defence comprises military activities (military defence) and civil activities (civil defence)" (SFS 1992:1403, 1 §).

The goal of civil defence consists of three mutually reinforcing parts: "Protect the civilian population, ensure the most important societal functions, and contribute to the Swedish Armed Forces' capability during an armed attack or war in our surroundings" (Försvarsdepartementet 2015a, page 59). Rather than being linked to any particular organisation, civil defence focuses on activities that ultimately affect most actors in society. Therefore, the term "civil defence" can be seen as a shorthand for the "total defence's civil parts", and these two expressions are used as synonyms in the following.

To emphasise the importance of civil defence, and the interaction with military defence, the Swedish government in 2015 decided to reinstate an overall total defence planning (Försvarsdepartementet 2015b). Various assignments (Justitiedepartementet 2015; Försvarsdepartementet 2017) have thereafter been given to the two main governmental organisations involved in military and civil defence, respectively, i.e. the Swedish Armed Forces and the Swedish Civil Contingencies Agency.

\section{Workshop results}

An important part of the project was to arrange a larger workshop where participants concerned with national interest and civil defence could contribute. The idea was both to communicate the work currently underway, and to get input from the participants to delimit and characterise the sector.

Invitations were sent to a number of governmental agencies and County Administrative Boards across Sweden. The participants were divided into five different groups, each comprising around 6-7 people representing their organisations. The background of the participants varied; some worked primarily with land-use planning whereas others had a focus on security and defence.

A key task during the workshop was to have the participants discussing possible examples of national interests for civil defence. The group were asked to come up with examples, and for each example outline four aspects to describe it: Activity, Facility, Area, and Needs. Activity concerned the operations that the facility contributes to, whereas Facility concerned the type of construction used in the activity. Area concerned land or water area of importance, and Needs the reasons why the area is needed. A total of 14 examples were generated by the participants collaborating in their groups, as shown in table 2 below.

\begin{tabular}{|c|c|c|c|c|}
\hline & Activity & Facility & Area & Needs \\
\hline 1 & $\begin{array}{l}\text { Transportation, } \\
\text { supply }\end{array}$ & Harbour & $\begin{array}{l}\text { Whole/parts of harbour } \\
\text { area (land and water), } \\
\text { depots }\end{array}$ & $\begin{array}{l}\text { Protection, } \\
\text { transportation }\end{array}$ \\
\hline 2 & $\begin{array}{l}\text { Lab analyses, } \\
\text { CBRNE }\end{array}$ & Research facility & Perimeter & $\begin{array}{l}\text { Transportation, } \\
\text { protection }\end{array}$ \\
\hline 3 & Water supply & Desalination plant & $\begin{array}{l}\text { Production and } \\
\text { distribution area }\end{array}$ & $\begin{array}{l}\text { Water intake, } \\
\text { transportation, } \\
\text { energy supply, } \\
\text { protection }\end{array}$ \\
\hline 4 & Fuel supply & $\begin{array}{l}\text { Harbour, depot, } \\
\text { refinery, truck \& road, } \\
\text { filling station }\end{array}$ & $\begin{array}{l}\text { Harbour area, depot } \\
\text { area }\end{array}$ & $\begin{array}{l}\text { Fulfil goals of civil } \\
\text { defence }\end{array}$ \\
\hline 5 & $\begin{array}{l}\text { Tele } \\
\text { communications }\end{array}$ & $\begin{array}{l}\text { Important } \\
\text { communication facility }\end{array}$ & Underground shelter & \\
\hline 6 & $\begin{array}{l}\text { Management, } \\
\text { communication, } \\
\text { collaboration }\end{array}$ & $\begin{array}{l}\text { Command and control } \\
\text { site and } \\
\text { communications }\end{array}$ & & $\begin{array}{l}\text { Manage civil defence, } \\
\text { support to Armed } \\
\text { Forces }\end{array}$ \\
\hline
\end{tabular}




\begin{tabular}{|c|c|c|c|c|}
\hline 7 & Supply & Harbour & & $\begin{array}{l}\text { Distribution, related } \\
\text { civil defence, Armed } \\
\text { Forces' conditions, } \\
\text { societal conditions }\end{array}$ \\
\hline 8 & $\begin{array}{l}\text { Emergency } \\
\text { healthcare }\end{array}$ & $\begin{array}{l}\text { Emergency hospital } \\
\text { and university hospital }\end{array}$ & $\begin{array}{l}\text { Buildings and } \\
\text { surrounding land areas } \\
\text { (above and below } \\
\text { ground) }\end{array}$ & $\begin{array}{l}\text { Access, supply, } \\
\text { logistics }\end{array}$ \\
\hline 9 & Electricity supply & $\begin{array}{l}\text { National, regional and } \\
\text { local grid with nodes } \\
\text { and control centres }\end{array}$ & $\begin{array}{l}\text { Areas in direct } \\
\text { proximity to the } \\
\text { facilities }\end{array}$ & $\begin{array}{l}\text { Physical protection } \\
\text { of facilities }\end{array}$ \\
\hline 10 & $\begin{array}{l}\text { Protection of } \\
\text { population during } \\
\text { air raids }\end{array}$ & Shelters & $\begin{array}{l}\text { Current shelters with } \\
\text { room for expansion, } \\
\text { areas for new shelters }\end{array}$ & $\begin{array}{l}\text { Existing shelters, } \\
\text { proper use, maintain } \\
\text { physical protection }\end{array}$ \\
\hline 11 & $\begin{array}{l}\text { Coordination of } \\
\text { operations }\end{array}$ & $\begin{array}{l}\text { Command and control } \\
\text { site }\end{array}$ & Small physical area & $\begin{array}{l}\text { Communication } \\
\text { system (e.g. Tetra- } \\
\text { based), electricity }\end{array}$ \\
\hline 12 & Supply & Bridge & $\begin{array}{l}\text { Small area (height above } \\
\text { / deep beneath) }\end{array}$ & $\begin{array}{l}\text { Ensure } \\
\text { communications }\end{array}$ \\
\hline 13 & $\begin{array}{l}\text { Fuel supply and } \\
\text { storage }\end{array}$ & Depot & Large areas & $\begin{array}{l}\text { Transportation, fuel } \\
\text { for backup power }\end{array}$ \\
\hline 14 & $\begin{array}{l}\text { Electricity } \\
\text { production }\end{array}$ & Nuclear plant & Land, water & $\begin{array}{l}\text { Transportation, } \\
\text { cooling, protection, } \\
\text { electricity }\end{array}$ \\
\hline
\end{tabular}

Table 2. Overview of examples produced by the participants of the workshop

\section{Key questions}

As described in the previous sections, material from the workshop was collected and analysed to get closer to a general sector description of National interest for civil defence, together with clarifying criteria to support the identification and evaluation of specific candidates. However, a gap in perspective was identified during a quest to attract participants for a second - this time internal - workshop targeted at employees of the agency having a focus on civil defence. The realisation was that much of the communication in the project, as well as the sector description and criteria themselves, might be of a larger interest to the land-use planning community than that of civil defence.

To close this gap, an extra step of analysis was inserted in order to form and address key questions of value for the civil defence community. This could be seen as an exercise in perspective switching, moving from the perspective of the solution (national interest) to the perspective of the need (civil defence). A total of five key questions were created from literature and workshop material and then answered. In addition to attracting the people interested in civil defence, the belief was also that the key questions, together with their answers, would contribute to a more usable sector description and corresponding criteria.

In an analysis best characterised as abductive (cf. Fann 1970), rather than purely deductive or inductive, the set of questions was arrived at after repeatedly going back and forth between the contexts of national interests and civil defence. The five questions eventually formed around the boundaries of civil defence, the contents of civil defence, the idea of national-level importance, the meaning of location and confinement, and the value of national interest for civil defence. Each question is addressed in a separate sub section below.

\subsection{Boundaries of civil defence}

What "civil defence" is, and what it is not, is a key question for the successful application of the legislation of national interests. It is also important for people interested in the area, as well as the general public, especially following the increased attention over the last couple of years. How to delimit and define a widely used term such as civil defence is seldom uncontested, and there can be reasons for the boundaries to be kept a bit vague, flexible and wide-ranging. Nevertheless, a shared awareness of the basic 
boundaries towards other areas is particularly helpful when people from different work practices and knowledge communities need to work together.

In defining civil defence, the initial focus will be on the second, main, part of the term and the boundary towards non-defence. "Defence" is used in different circumstances, and common dictionaries defines it along the lines of "the act or action of defending", with "defend" meaning "to drive danger or attack away from" (Merriam-Webster n.d.). Hence, defence imply activities where somebody/something (the defender) defends somebody/something (the defendee) against somebody/something (the danger or attack). In practical use, "defence" often also covers related activities of preventing, planning, evaluating, improving, etc, the actual moments of defending.

Analysing the broad range of activities that the term "defence" applies to, they can be projected along several dimensions. Most notable, this includes differences in scope and severity, and also whether the defence is aimed at somebody's attack or something dangerous. Examples include an attack from foreign armed forces, a terrorist or a robber. Or the dangers of a pandemic, a flooding, or a domestic fire. Partially because of the association of the term "defence" with specific organisations in most countries that represent some kind of armed defence forces, defence against foreign armed forces are often seen as more prototypical than defence against for example a domestic fire. As seen earlier, this is mirrored in the legislation for Sweden's total defence where the first sentence read "Total defence are activities needed to prepare Sweden for war" (SFS 1992:1403).

As there are no clear-cut boundaries between "defence" and for example "protection" and "preparedness" the differences towards related terms are sometimes more of difference in degree than a difference in kind. The rough boundary implied by the legislation seem to be contextual and hinge on the societal situation, so that actual moments of defending only happens in situations of heightened alert, but that related activities of preventing, planning, evaluating, improving the defence may and should happen also in other situations. In the planning of the civil defence, the government noted that "it is important that lessons learned and resources from accident protection and emergency preparedness also are used for planning the civil defence. In several respects, the goal for emergency preparedness is matched by the goal for civil defence. However, the government believes that civil defence requires additional activities that have not been deemed necessary for emergency preparedness. This could for example include demands for certain protection activities, certain important society functions, and that scarce resources can be distributed to prioritised activities in heightened alert" (Försvarsdepartementet 2015a, page 60).

Turning to the first part of the term "civil defence", it is now possible to discuss the boundary towards other forms of defence, thereby further clarifying the delimitations of total defence's civil parts. Potentially, the prefix "civil" could be used as a delimiter in each of the three different aspects of defence identified above: regarding either the defender, the defendee, or the danger/attack. Going back to the underlying legislation, where civil defence was described alongside military defence as the two parts comprising total defence (SFS 1992:1403), it is clear that the prefix is in fact a delimitation focusing on the first of these dimensions, distinguishing a certain type of defender. Military defence is hence performed by armed forces whereas civil defence is performed by other, non-military, actors. The distinction between armed forces and civilians is defined in the Geneva Convention, especially protocol 1 (United Nations 1977). However, please note that in the Geneva Convention, "civil" in "civil defence" is primarily used as a delimitation of the defendee, i.e. what is being defended, rather than of the defender.

Notwithstanding the above, in the legislative context of national interests the precise division between civil and military defence is of no real significance as all of total defence is included, but rather a practical matter in terms of division of labour between different governmental organisations. For example, in the current claims for national interests for total defence, the Swedish Armed Forces states that "In the concept military defence, also civil agencies within the defence sector are included, such as the Swedish Defence Research Agency, the National Defence Radio Establishment, and Swedish Defence Materiel Administration, whose interests the Swedish Armed forces represents" (Försvarsmakten 2015, page 4). Moreover, the Swedish Armed Forces also handles national interest claims regarding weather radar stations owned by Swedish Meteorological and Hydrological Institute, something that could change if Swedish Civil Contingencies Agency were to begin handling civil defence national interests in the future.

\subsection{Contents of civil defence}

Whereas the first question about delimitation looked at civil defence more or less as a black box, the question of content opens up the box to look at its constituents. In the same way as an extensional definition complements an intensional definition, exploring the contents of civil defence can be as valu- 
able as defining its boundaries. Irrespectively of whether the exploration of content is aiming for a complete list, or only a list of examples, the result can be helpful not only for finding and/or evaluating specific proposals for national interests, but also for understanding and developing civil defence for a wider audience.

Different things that can be found within the boundaries of civil defence, and these can be divided in different ways. Because civil defence is ultimately about activities performed, focusing on the ways these activities are characterised and grouped will add to the insights into the contents of civil defence. As stated by the Swedish government, "Civil defence consists of activities that responsible actors performs to make it possible for society to deal with situations of heightened alert. Civil defence is therefore not an organisation. The activities are performed by governmental agencies, municipalities, counties, private businesses, and voluntary organizations" (Försvarsdepartementet 2015a, page 12).

We will use the goal of Swedish civil defence mentioned earlier as a starting point, using its three parts. The first part, "protect the civilian population", has been the traditional focus of civil defence after World War II. As noted above, the Geneva Convention embody this notion when it presents a list of specific tasks following the statement that "civil defence" means "the performance of some or all of the undermentioned humanitarian tasks intended to protect the civilian population against the dangers, and to help it to recover from the immediate effects, of hostilities or disasters and also to provide the conditions necessary for its survival" (United Nations 1977).

The second part of the goal, "ensure the most important societal functions", focus on the workings of society to make sure that its key activities are operating also in difficult times. In 2010, the Swedish government commissioned the Swedish Civil Contingencies Agency to develop a strategy for the protection of vital societal functions (MSB 2011). In the strategy, "a vital societal function is defined as a function of such importance that its loss or severe disruption to it could entail major risks or hazards for the life and health of the population, the functionality of society or society's fundamental values" (MSB 2011, page 10). A total of 11 societal sectors, in which vital societal functions may be found, were identified: Energy supply; Financial services; Foodstuffs; Health, medical and care services; Information and communication; Public administration - management; Safety and security; Social insurance; Technical municipal services; Trade and industry; and Transport (MSB 2011, page 21).

The third and final part of the goal, "contribute to the Swedish Armed Forces' capability during an armed attack or war in our surroundings", focus on areas where civil defence may support the military defence in certain circumstances. Relevant areas may of course vary over time, but some have been stated by the Government: "For example, transportation and logistics, supply of food, fuel, electricity and telecommunications, and access to healthcare resources will make up special needs for the military defence" (Försvarsdepartementet 2015a, page 108).

\begin{tabular}{|c|c|c|c|c|}
\hline Cooperation area & $\begin{array}{l}\text { Societal sector } \\
\text { (approximate match only) }\end{array}$ & $\begin{array}{l}\text { Protect } \\
\text { civilians }\end{array}$ & $\begin{array}{l}\text { Ensure } \\
\text { society }\end{array}$ & $\begin{array}{l}\text { Contribute } \\
\text { capability }\end{array}$ \\
\hline $\begin{array}{l}\text { Hazardous } \\
\text { substances }\end{array}$ & Protection, safety and security & $\mathrm{X}$ & $\mathrm{X}$ & \\
\hline $\begin{array}{l}\text { Protection, rescue } \\
\text { and care }\end{array}$ & Health, medical and care services & $\mathrm{X}$ & $\mathrm{X}$ & $\mathrm{X}$ \\
\hline $\begin{array}{l}\text { Economic } \\
\text { security }\end{array}$ & $\begin{array}{l}\text { Financial services } \\
\text { Social security } \\
\text { Trade \& industry }\end{array}$ & & $\mathrm{X}$ & \\
\hline $\begin{array}{l}\text { Geographic } \\
\text { responsibility }\end{array}$ & Public administration & & $\mathrm{X}$ & \\
\hline $\begin{array}{l}\text { Technical } \\
\text { infrastructure }\end{array}$ & $\begin{array}{l}\text { Energy supply } \\
\text { Information and communication } \\
\text { Municipal technical services } \\
\text { Foodstuffs }\end{array}$ & & $\mathrm{X}$ & $\mathrm{X}$ \\
\hline Transportation & Transport & & $X$ & $\mathrm{X}$ \\
\hline
\end{tabular}

Table 3. Overview of contents of civil defence based on cooperation areas 
Having looked at each of the parts of the goal for civil defence, we can now turn to how relevant legislation structures the actual work. In addition to the provisions given to a number of governmental agencies, assigned as "responsible for monitoring", a set of six different cooperation areas are used, where each of these agencies participate in one or more areas. The areas are Hazardous substances; Protection, rescue and care; Economic security; Geographic responsibility; Technical infrastructure; and Transportation (SFS 2015:1052). The legislation states that "In order to facilitate a holistic view in the planning for emergency preparedness and heightened alert, the planning for agencies listed in the appendix to this ordnance should be performed within cooperation areas" (SFS 2015:1052, 7 §).

Table 3 above shows the contents of civil defence in terms of the six cooperation areas, alongside the societal sector(s) most closely matching, and the part(s) of the goal aimed at. Although precise delimitations are not strictly needed for working with national interests, the areas outlined contribute to make civil defence more concrete when identifying and evaluating claims for national interests.

\subsection{Importance on a national level}

One cornerstone of the general system of national interests is the idea that certain areas of the country are important on a national level. For civil defence, the importance of a geographical area is largely linked to the facilities that may be created or used on that location. Depending on how easy it is to qualify for an interest to be important on a national level, the number of claims for national interests can be expected to range from very few to an endless number.

The governmental agency responsible for the national interest system - National Board of Housing, Building and Planning - outlines three general criteria for something being of national interest: large national value, committed internationally, or nationally important structures (Ryding 2017). Whereas the first and last case could be said to concern what is directly important to the population, the middle case concerns requirements to fulfil commitments the nation has made to other countries, thereby concerning the population more indirectly.

Looking more closely at the first case, this can be seen as the prototypical example of when something is of important on a national level. This represent the case when there are no, or only a few, alternatives available to something of value to the population. Examples could include the place where the national parliament resides, or a rocket launching range. Here the whole population, or a large portion thereof, could be said to be reliant on the specific area and its facilities.

The third case opens up the possibility that something can be of national importance by virtue of being part of a larger structure. As noted by the representative of the Swedish Civil Contingencies Agency in this project, there are three different alternatives when also parts can be of national importance. One alternative concerns parts of physical infrastructures, for example a railroad station. The other alternative concerns parts of information infrastructures, for example a communication tower. The final alternative concerns decentralised parts with multiple forms of interaction among them, for example a hospital.

Although a specific part of a larger structure in itself may not be of value to the whole population, or a large portion thereof, its demise may have significant repercussions on a larger scale and thereby making it important also on a national level. In the context of national interests, this will perhaps require a bit more judgement compared to the first two cases where the direct or indirect value to a large portion of the population might be easier to establish.

\subsection{Location and confinement for civil defence}

When working with national interests, the question is not only if something is important on a national level, but also how confined and dependent it is on the particular location. Because national interests deals with specific areas of land and water, a key question is what this means for the activities being performed, whether it is the place for the national parliament or a hospital. Basically, the easier it is to move a civil defence activity to another location, the weaker the argument is to judge its current location as an area of national interest.

In general, an activity can be more or less confined to a specific location. For example, it is easier to perform mental calculations in various locations than it is to launch a rocket into space. The main difference lies in the materials and surroundings needed to perform the activity. While some material is easy to move to another location, other is more permanently fixed. Prime examples of the latter are buildings, factories and infrastructure - hence the recurring focus on facilities in the context of national interests. 
Compare the situations of performing healthcare at a fixed emergency hospital and at a mobile field hospital. Whereas the former requires considerable time, energy and money to move, the latter is less confined to its current location and can easier be moved to a different place. In addition to the confinement due to the facilities and materials, the issue of surroundings can be equally challenging. Even if the time, energy and money to move can be mustered, there might be few, if any, alternative locations available. The same applies to cases of future facilities, where forthcoming civil defence activities may require new facilities in certain locations.

\subsection{Value of national interest for civil defence}

The final key question concerns when national interest is of value for civil defence. As with all tools, their value depends on the specific context and the needs within that context. For people engaged in civil defence, this means realising the specific advantages that national interest might have on the activities and goal of civil defence. But equally important, to understand the limitations, and possible drawbacks, of national interest in the context of civil defence.

As described in this paper, the legislation for national interests is designed to influence the individual decisions made to change the utilisation of land and water. Whether related to a building permit for a new house, or the concession for a new highway, the decision makers are obliged to take existing national interests into account when making their decisions. For the Swedish Civil Contingencies Agency to take up the role of responsible for national interests for civil defence, there has to be enough advantages to top possible disadvantages.

Starting with the pros, one advantage is that national interests might make future expansions easier for civil defence in existing locations. Or that additional facilities might become easier to establish in new locations. Another advantage is that national interests might make reduce the limitations posed on civil defence activities by changes in the surrounding environment. Or that the activities eventually become so negatively affected that the only alternative is for them to have to move. A third advantage is that national interests provides an opportunity for civil defence to examine and possibly rethink its activities and use of facilities. Exploring the conditions of national importance and confinement to specific locations, might yield important insights also when a possible claim for national interest turn out not to be applicable or beneficial.

A possible disadvantage is that claims for national interests are tested anew in each decision, which means that there are no guarantees that they will prevail every time. Although national interests for civil defence carry more weight than other national interests, much of the outcome hinges on how well the interest is motivated. Another possible disadvantage is that the whole system of national interests is designed for transparency and openness. Although the Swedish Armed Forces have devised procedures for also handling secret facilities, the basic premise of national interests is that of non-secrecy.

\section{Conclusions}

In the project conducted, material for a sector description, together with accompanying criteria, have been developed. This was done through existing literature, a workshop with a large number of invited representatives for different governmental agencies, and recurring discussions within the project group. Putting the different fragments together yielded a proposed sector description along the following lines:

"Civil defence comprises defence-related activities performed by civil actors during, and in preparation for, heightened alert. The activities are pertinent to the goal of civil defence, and are relevant for at least one of the cooperation areas for emergency preparedness and heightened alert. In cases where the activities are dependent on facilities and equipment not easily relocated, and they are directly or indirectly important for a significant portion of Sweden's population, appropriate areas of land or water are candidates for national interests for civil defence".

This paper has shown how data from two disparate areas have been used in a collaborative exploration effort to facilitate upcoming decisions and strengthen strategic resilience. These decisions include both the general one, whether to start handling actual national interest claims for civil defence, and if so, the specific decisions dealing with individual claims. In addition to the Swedish Civil Contingencies Agency, this collaboration also involves the other actors being represented at the reported workshop, since a successful solution will depend on the participation of a range of different actors. Although the sector description being evolved will embody a condensed version of the knowledge gained, many of the benefits with the project have to do with the underlying work to build a shared understanding between the two areas of land-use planning and total defence. 

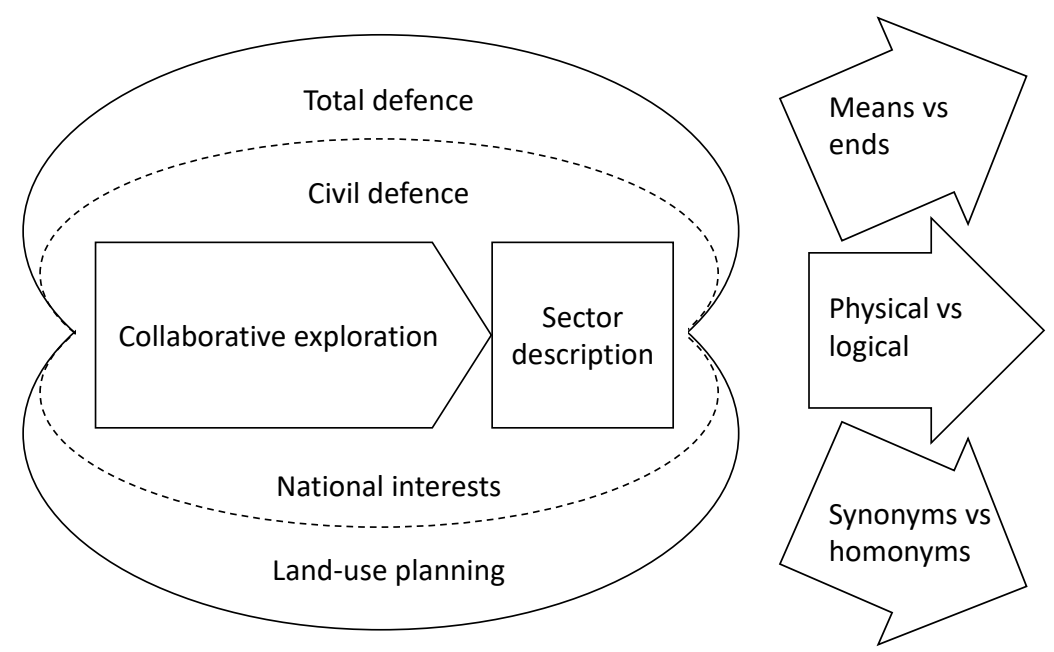

Fig. 1. Specific and general results of the project.

As summarised by Figure 1, the paper has also provided more general insights into critical challenges arising in collaborative exploration efforts. First, this include challenges of sense-making (Weick 1979), with divergent meanings of common words used in both contexts, for example the notion of "protection". In the context of civil defence, protection is primarily conceived against an adversary whose threats could have immediate consequences of destroyed property or lost lives. In national interests, protection is instead primarily conceived against official decisions that could have long-term consequences and ultimately lead to activities having to scale-down or relocate.

Second, the paper illustrates the challenges of bridging logical and physical issues in development work, navigating the fundamental distinction between infological and datalogical aspects of the world (Langefors 1993). Whereas it often is important to be able to let go of physical constraints in order to realise underlying needs and devise new possibilities, many working solutions require physical artefacts and surroundings that exist in specific places and have specific characteristics.

Third, the paper shows how the exploration of means and ends provides important challenges when problems are set and solved. Whether it is a new information system that provides benefits to a business (Markus and Keil 1994), or as in this case, a piece of legislation that can be used as a tool towards certain goals of an organisation or society in general. In each case, there is a need for 'customers' to express needs and requirements, and 'suppliers' to express value and benefits.

\section{References}

Boverket. 2013. Riksintressen - nationella värden och möjligheter [National interests - National values and possibilities], Karlskrona, Sweden: Boverket [National Board of Housing, Building and Planning].

Fann, K.T. 1970. Peirce's Theory of Abduction, The Hague, The Netherlands: Martinus Nijhoff.

Försvarsdepartementet, 2015a. Försvarspolitisk inriktning - Sveriges försvar 2016-2020 [Defence policy - Sweden's defence 2016-2020], Proposition 2014/15:109, Stockholm: Regeringen [Government Offices of Sweden].

Försvarsdepartementet, 2015b. Uppdrag till Försvarsmakten och Myndigheten för samhällsskydd och beredskap avseende totalförsvarsplanering [Assignment to the Swedish Armed Forces and the Swedish Civil Contingencies Agency regarding total defence planning], Regeringsbeslut 5, Stockholm: Regeringen [Government Offices of Sweden].

Försvarsdepartementet, 2017. Uppdrag till Försvarsmakten och Myndigheten för samhällsskydd och beredskap att främja och utveckla en sammanhängande planering för totalförsvaret [Assignment to the Swedish Armed Forces and the Swedish Civil Contingencies Agency regarding facilitating and developing a holistic planning for total defence], Regeringsbeslut 2, Stockholm: Regeringen [Government Offices of Sweden].

Försvarsmakten, 2015. Redovisning av riksintressen och områden av betydelse för totalförsvarets militära del enligt 3 kap $\$ 9$ Miljöbalken i Stockholms län [Description of national interests and areas of significance for total defence's military part according to 3 chapter $\S 9$ Environmental 
code in Stockholm county], Appendix to FM2015-3297:1, Stockholm: Högkvarteret, Försvarsmakten [Swedish Armed Forces].

Glaser, B.G. and Strauss, A.L. 1967. The Discovery of Grounded Theory: Strategies for Qualitative Research, New Brunswick, NJ: Aldine.

Holling C.S. 1973. "Resilience and stability of ecological systems", Annual Review of Ecology and Systematics, Vol. 4, pp. 1-23.

Justitiedepartementet, 2015. Planeringsanvisningar för det civila försvaret [Planning directive for civil defence], Regeringsbeslut II:16, Stockholm: Regeringen [Government Offices of Sweden].

Keen, P.G.W. 1991. "Relevance and Rigor in Information Systems Research: Improving Quality, Confidence, Cohesion and Impact in Information Systems Research", in Nissen, H.E., Klein, H. and Hirschheim, R. (eds.) Contemporary Approaches and Emergent Traditions, pp. 27-49, Amsterdam, The Netherlands: Elsevier Science Publishers.

Langefors, B. 1993. Essays of Infology, Gothenburg Studies in Information Systems, Report 5, Göteborg, Sweden: University of Göteborg.

Markus, M.L. and Keil, M. 1994. "If We Build It, They Will Come: Designing Information Systems That People Want to Use", Sloan Management Review 35(4).

Merriam-Webster. n.d. "Defense" and "Defend", Retrieved May 23, 2018, from https://www.merriamwebster.com/dictionary

MSB, 2011. A functioning society in a changing world: The MSB's report on a unified national strategy for the protection of vital societal functions, MSB 341, Karlstad, Sweden: Myndigheten för samhällsskydd och beredskap [Swedish Civil Contingencies Agency].

Nelson, D.R., Adger, W.N. and Brown, K. 2007. "Adaptation to environmental change: contributions of a resilience framework", Annual Review of Environment and Resources, Vol. 32, pp. 395-419.

Ryding, O. 2017. Riksintressesystemet [The national interest system], Presentation 2017-05-22, Karlskrona, Sweden: Boverket [National Board of Housing, Building and Planning].

Schein, E.H. 1987. The Clinical Perspective in Fieldwork, Vol 5, Qualitative research methods series, Thousand Oaks, CA: Sage Publications.

SFS 1992:1403. Lag om totalförsvar och höjd beredskap [Act for total defence and heightened alert], Stockholm: Försvarsdepartementet [Ministry of Defence].

SFS 1998:808. Miljöbalk [Environmental code], Stockholm: Miljö- och energidepartementet [Ministry of the Environment and Energy].

SFS 1998:896. Förordning om hushållning med mark- och vattenområden [Ordinance for husbandry of land and water areas], Stockholm: Miljö- och energidepartementet [Ministry of the Environment and Energy].

SFS 2015:1052. Förordning om krisberedskap och bevakningsansvariga myndigheters åtgärder vid höjd beredskap [Ordinance for emergency preparedness and tasks during heighened alert of agencies with monitoring resposibility], Stockholm: Socialdepartementet [Ministry of Health and Social Affairs].

United Nations, 1977. Protocol additional to the Geneva Conventions of 12 August 1949, and relating to the protection of victims of international armed conflicts (Protocol I), I-17512, UN Treaty Series Vol. 1115, New York: United Nations.

Weick, K.E. 1979. The Social Psychology of Organizing, Second edition, New York: McGraw-Hill.

Yin, R.K. 2003. Case Study Research - Design and Methods, Third edition, Thousand Oaks, CA: Sage Publications Inc.

\section{Acknowledgements}

The author is very grateful to the Swedish Civil Contingencies Agency and its two representatives for providing valuable feedback on this paper. The author also acknowledges much appreciated collaboration with his colleague Helena Brandt and support from Combitech $\mathrm{AB}$, the consulting company they both worked for during the project described. 


\section{Copyright}

Copyright: (C) 2018 authors. This is an open-access article distributed under the terms of the Creative Commons Attribution-NonCommercial 3.0 Australia License, which permits non-commercial use, distribution, and reproduction in any medium, provided the original author and ACIS are credited. 